\title{
SOFTWARE FOR MONITORING A GRID CONNECTED PHOTOVOLTAIC POWER PLANT
}

\author{
P. Tsankov ${ }^{*}$ \\ Technical University of Gabrovo, Faculty of Electrical Engineering and Electronics \\ 4 Hadji Dimitar Str., 5300 Gabrovo, Bulgaria
}

\begin{abstract}
Summary: This paper presents the software products serving the monitoring system of the $10 \mathrm{kWp}$ grid connected photovoltaic power plant in the Technical University of Gabrovo. Software products for monitoring meteorological and electrical operational parameters, electricity production and web-based database for the PV system have been developed. Information about the software development environment, programming stages and programs functionality is presented.
\end{abstract}

Keywords: amorphous and polycrystalline silicon photovoltaic modules, PV system monitoring, block diagram-based software development

\section{INTRODUCTION}

In the period 2003-2006, as part of European PV Enlargement project at the Technical University - Gabrovo, a $10 \mathrm{kWp}$ photovoltaic system was built [1]. The photovoltaic system is connected to electricity distribution network and consists of three subsystems. The first and second subsystem with single installed power of $3.42 \mathrm{kWp}$ are identical, each containing 12 polycrystalline silicon PV modules of type ASE-250 DG-FT/MC. The third subsystem with power of $3.22 \mathrm{kWp}$ is built from a field of 100 amorphous silicon PV modules of type ASE-F 32/12.

Consequently, a monitoring system was built for measurement, storage and transmission of the following data [2]:

- Global solar radiation;

- Solar radiation in the plane of PV modules;

- Temperature of two types of PV modules;

- Temperature of the silicon reference cell;

- Ambient temperature;

- Current, voltage and power of the DC side of three subsystems;

- DC and AC energy produced by three subsystems;

- Total energy produced by the PV system.

Effective use of different monitoring devices, sensors and transducers require appropriate software support. This article presents the development of software for monitoring the PV system at the Technical University of Gabrovo.

\section{EXPOSITION}

2.1. Development of software for monitoring meteorological and electrical operational parameters of the photovoltaic system

All the measuring device and sensor signals are converted into the appropriate $4 \div 20 \mathrm{~mA}$ standard type current loop by isolated converters ISC - Figure 1 . Then the signals are connected to UDAS Data Acquisition System - Figure 2. UDAS is a stand-alone, multifunctional, plug-and-play data acquisition system that is connected to the Universal Serial Bus of personal computer and operates using the power supplied through any USB connector. The system features: analogue inputs ( 8 differential, 16 single-ended), digital I/O (Two 8-bit ports, each port configurable to input or output), and one counter channel. Block diagram of UDAS is shown in Figure 3 [3]. Figure 4 presents detailed information about the connection of different sensors to the inputs of UDAS.

Software support for the UDAS monitoring system is built on the specialized software package for high-level programming Visual Designer [4,5]. Visual Designer is a block diagram-based application construction program designed to run in Windows OS. It allows developing custom data acquisition, analysis, display, and controlling programs simply by drawing a program's data flow structure in the form of a block diagram, or in Designer terminology, a FlowGram. Further, OLE and other programming objects can be embedded in a FlowGram and links can be made between the objects in a FlowGram and disk files.

*Corresponding author: plamen@tugab.bg 


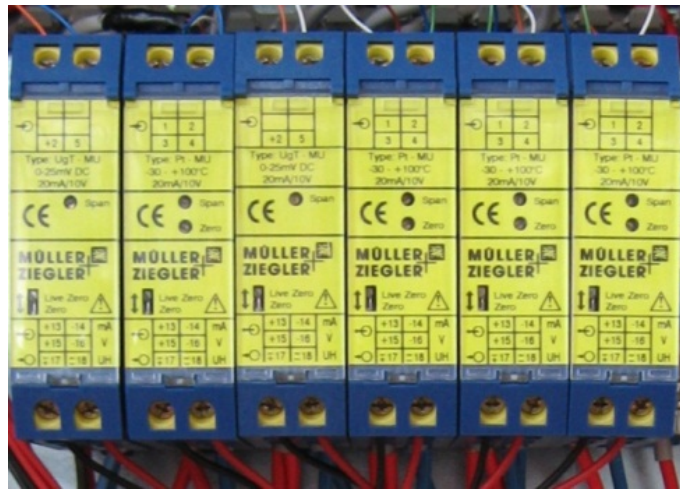

Figure 1. Isolated converters (ISC)

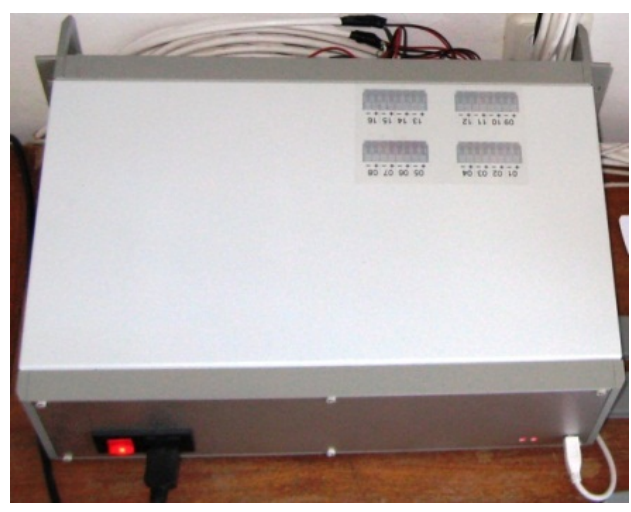

Figure 2. UDAS Data Acquisition Unit

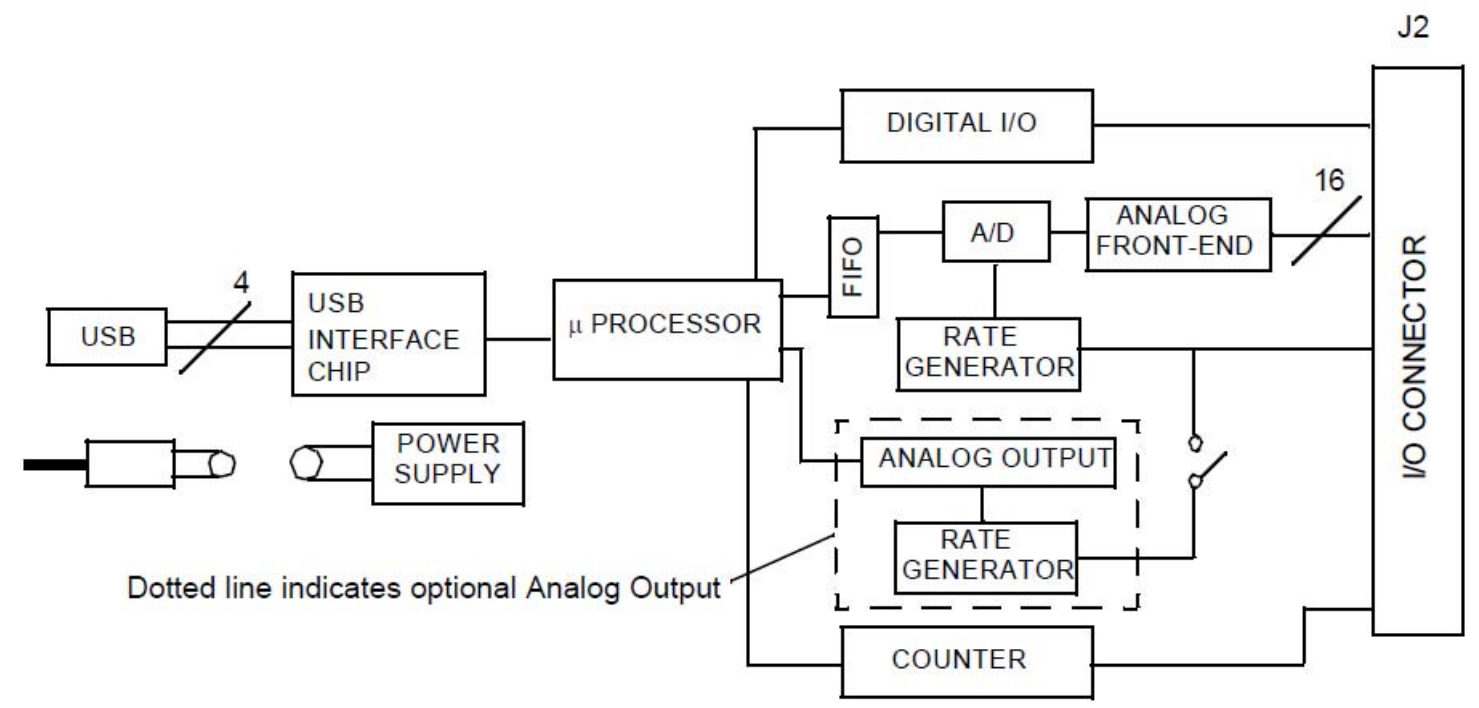

Figure 3. UDAS system block diagram

Figure 5 shows the FlowGram of software developed for monitoring the PV system at the Technical University of Gabrovo. For ease of explanation FlowGram is divided into four main elements - marked with I, II, II and IV in Figure 5. Each element is conditionally divided into subitems.

In Figure 6 element $I$ is extracted (from the FlowGram) which is divided into four sub-items. Sub-item 1 consists of six specialized modules. It accepts a 16 - bit signal from the hardware device (UDAS) system and converts it into a form convenient for reading the Visual Designer program. After processing the signal from the sub-item one, it is submitted by the analogue input to component II of the program. Sub-items 2 and 4 are used for display of labels for different measured parameters on the front panel of the program. Sub-item 3 performs two functions. The first one is to read astronomical date and hour of the computer and the other one is to perform an action on the program at some date and time. In this case, the program automatically starts at 03:50 $\mathrm{h}$ and stops at 23:30 $\mathrm{h}$ each day.

The logic for processing the data stream from the hardware device is programmed in element II. Figure 7 shows the content of element II. Block „Dataln" is input from the analogue output of element I. From this data flow goes to "Unpack 1" element, where data bits from $0-7$ ( $1 \div 8$ channels) are separated to go into the first data accumulator, and

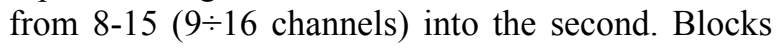
"Calc+Display” process all the data from the hardware device and then information is displayed on the front panel display of the monitoring software.

Figure 8 shows the FlowGram of the data processing programming module for the first eight sensors $(1 \div 8$ channels $)$ as follows:

- Sensor 0 - Global irradiance $\left[\mathrm{W} / \mathrm{m}^{2}\right]$;

- Sensor 1 - Ambient air temperature $\left[{ }^{\circ} \mathrm{C}\right]$; 
- Sensor 2 - Plane irradiance $\left[\mathrm{W} / \mathrm{m}^{2}\right]$;

- Sensor 3 - Temperature of the reference cell $\left[{ }^{\circ} \mathrm{C}\right]$;

- Sensor 4 - Polycrystalline silicon module temperature for subsystem $1\left[{ }^{\circ} \mathrm{C}\right]$;

- Sensor 5 - DC voltage subsystem $1[\mathrm{~V}]$;

- Sensor 6 - DC current subsystem 1 [A] ;

- Sensor 7 - AC power subsystem $1[\mathrm{~kW}]$; $1[\mathrm{~kW}]$.

- Calculated power - DC power subsystem

Figure 9 shows the FlowGram of the data processing programming module for the second part of sensors $(9 \div 16$ channels) as follows:

- Sensor 0 - Amorphous silicon module temperature for subsystem $3\left[{ }^{\circ} \mathrm{C}\right]$;

- Sensor 1 - DC voltage subsystem $3[\mathrm{~V}]$;

- Sensor 2 - DC current subsystem $3[\mathrm{~A}]$;

- Sensor 3 - AC power subsystem $3[\mathrm{~kW}]$;

- Sensor 4 - DC voltage subsystem 2 [V];
- Sensor 5 - AC power subsystem $2[\mathrm{~kW}]$;

- Sensor 6 - DC current subsystem 2 [A] ;

- Calculated power - DC power subsystem 2 $[\mathrm{kW}]$

- Calculated power - DC power subsystem 3 $[\mathrm{kW}]$.

After receiving the data from element II, values are displayed in real time on the front panel display of monitoring software. Simultaneously, the data goes into accumulators. In the accumulators each signal passes through another sub-FlowGram Figure 10. In this sub-program measured signals are processed and at every 10 minutes minimum, average and maximum values are accounted and stored for every measured or calculated parameter. From this sub-FlowGram data stream is fed into the outputs in special archivers and goes to element III of the program shown in Figure 11.

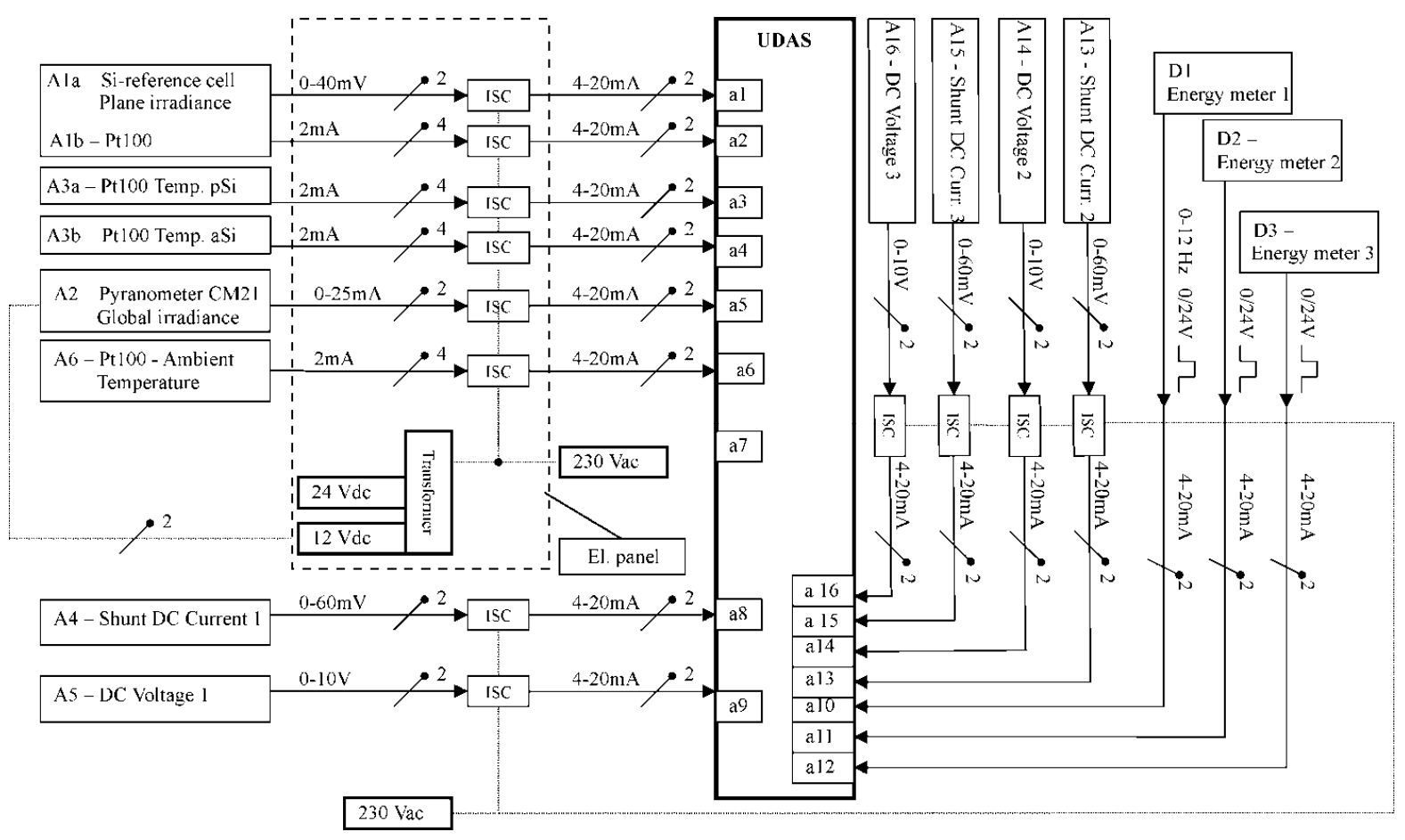

Figure 4. Connection of sensors to the inputs of UDAS 


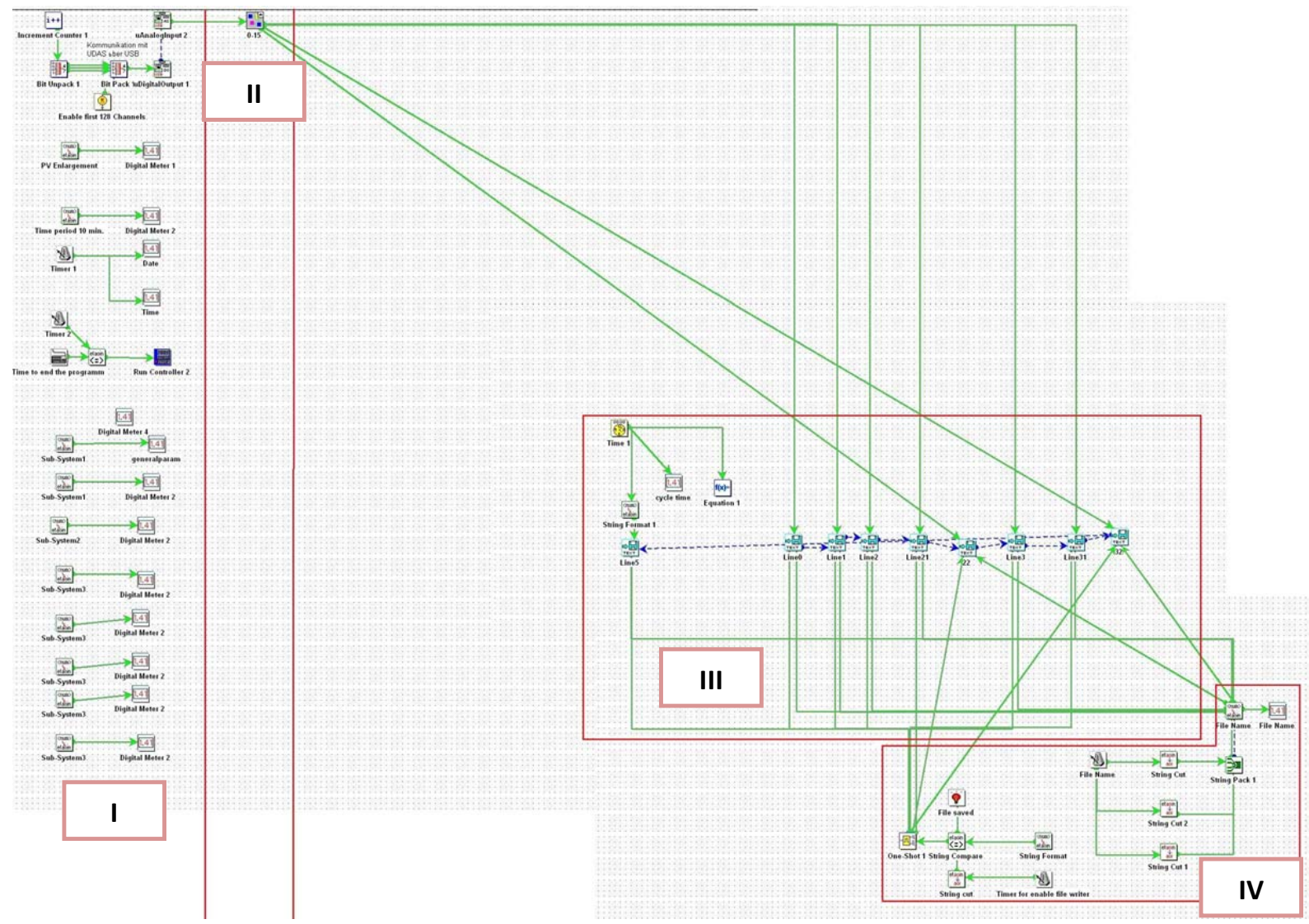

Figure 5. FlowGram developed for UDAS monitoring unit of the PV system

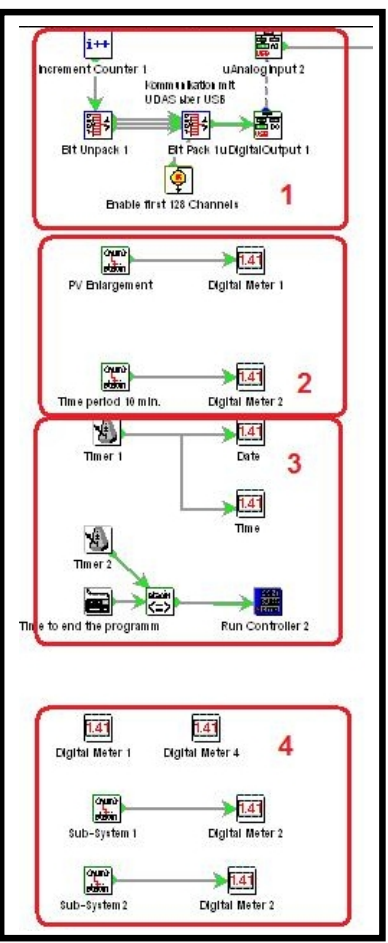

Figure 6. FlowGram - element I

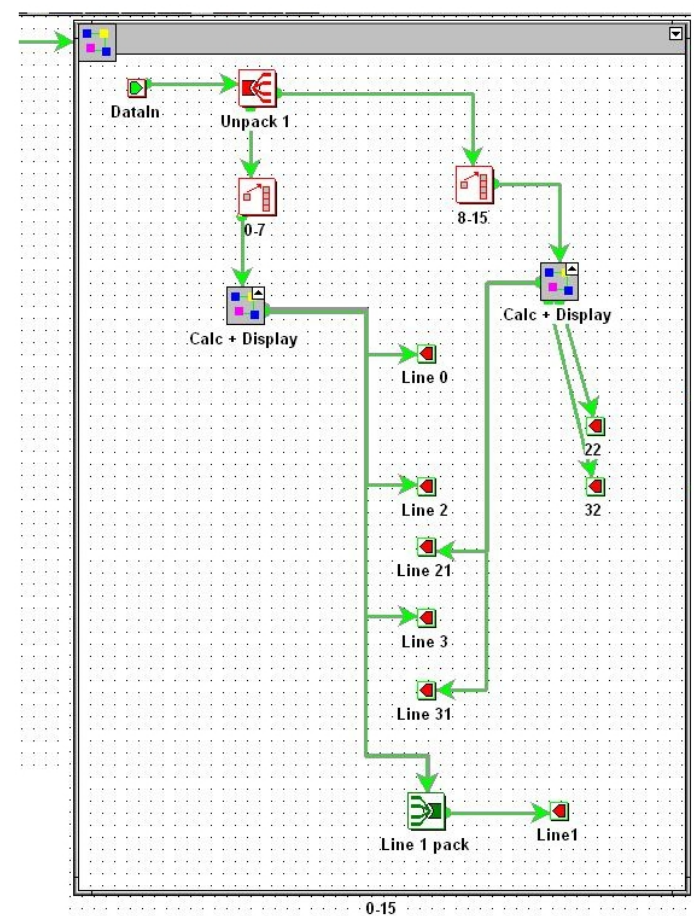

Figure 7. FlowGram - element II 


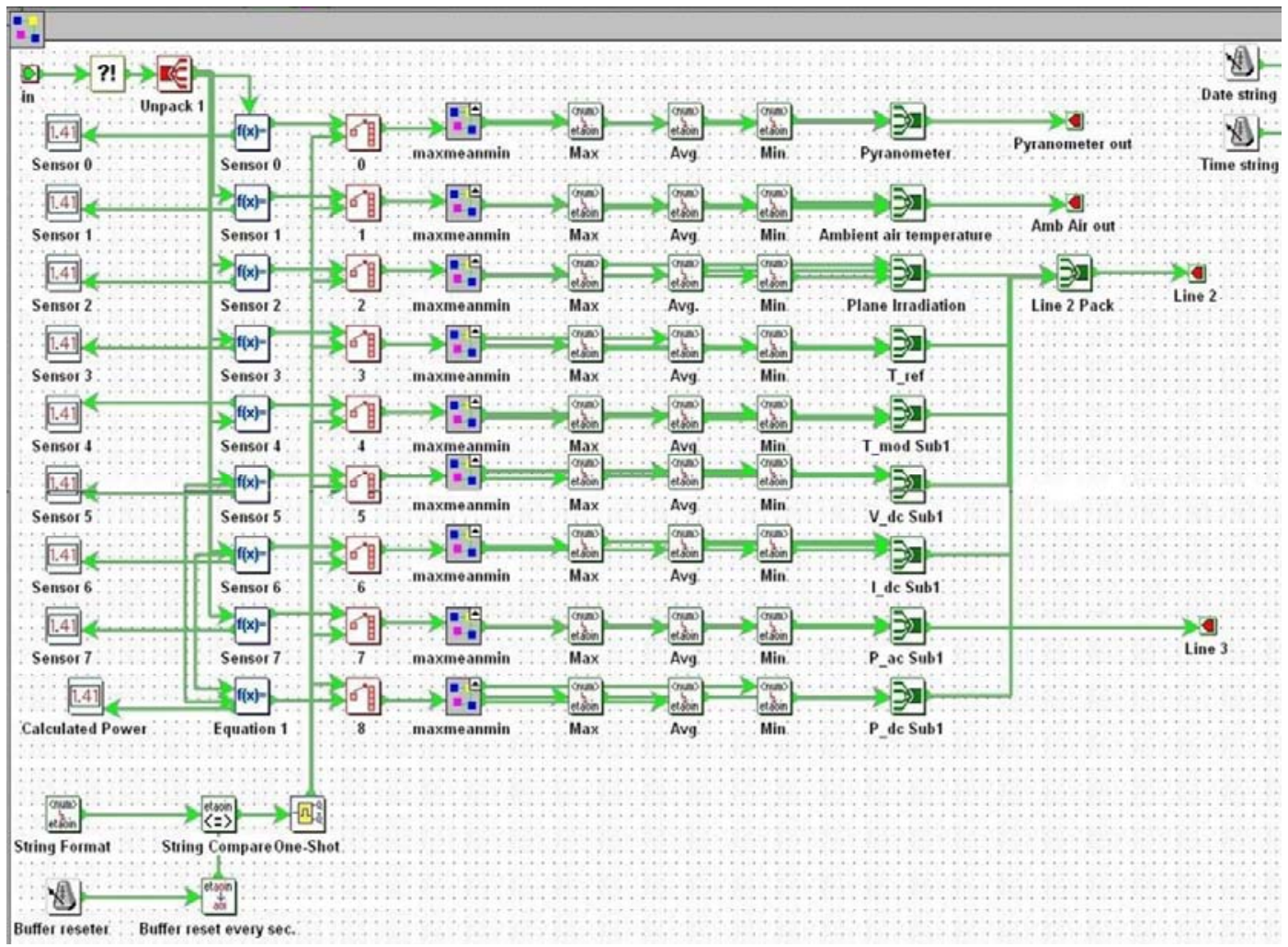

Figure 8. FlowGram - data processing of the $1 \div 8$ channels

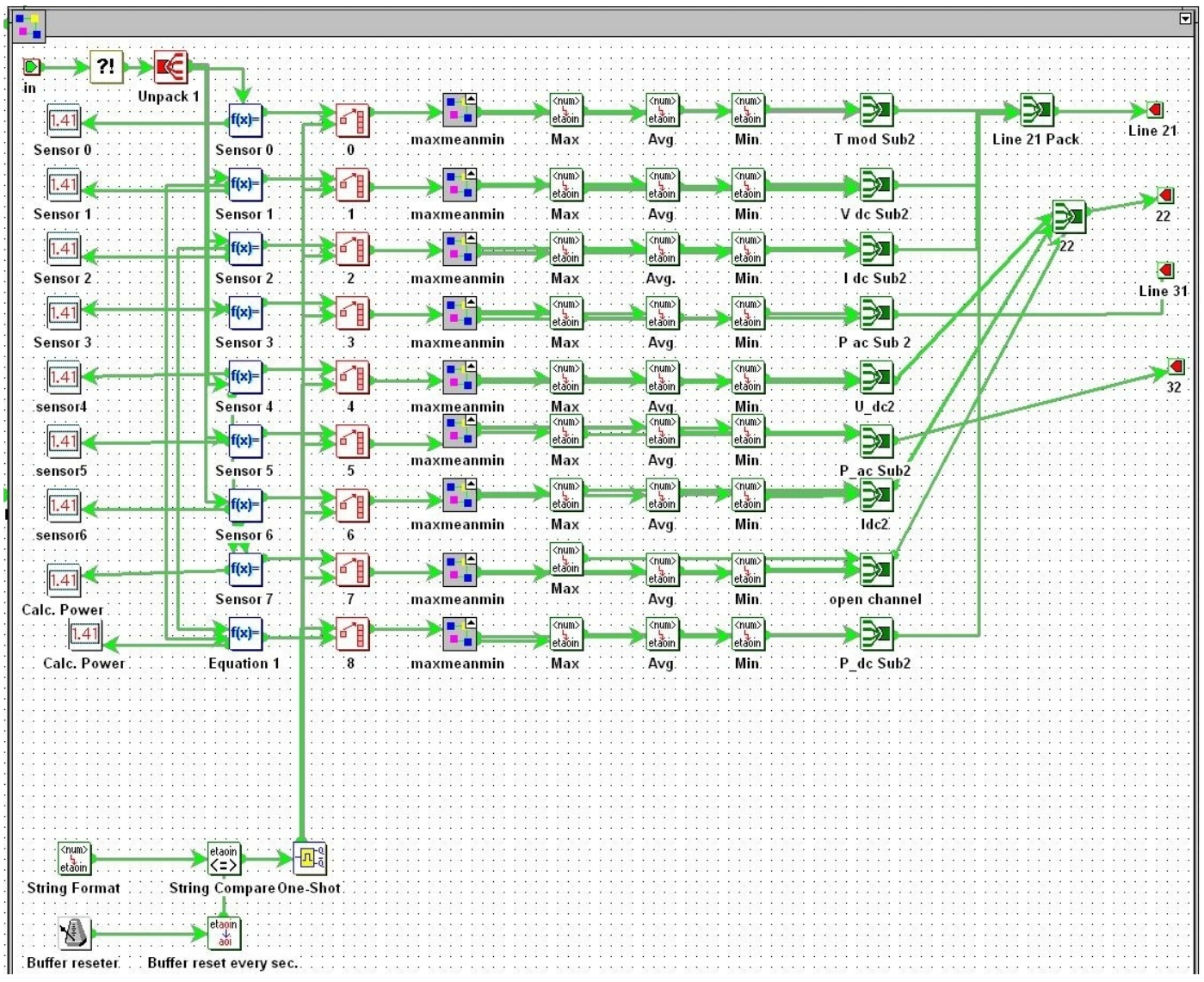

Figure 9. FlowGram - data processing of the 9 $\div 16$ channels 


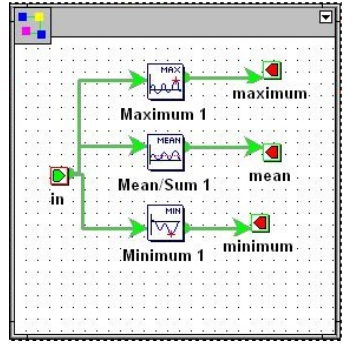

Figure 10. In the accumulators each signal passes through another sub-FlowGram

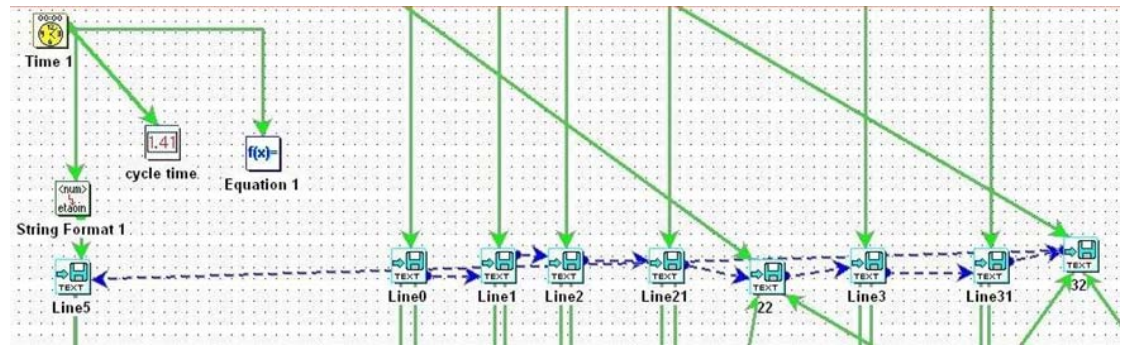

Figure 11. Sub-FlowGram data stream is fed into the outputs in special archivers and goes to element III of the program shown
The function of element III is to sort incoming data stream in a strict order according to the PV Enlargement project format. Then using the functions of the element IV of the main FlowGram all the monitoring data is saved in text files - Figure 12.

Figure 13 shows the front panel of the software for monitoring the PV system of TU Gabrovo. The panel has three main fields with measured and calculated values for every subsystem.

In the fields real time values are displayed for: module temperature, DC current, DC voltage, DC power, AC power and inverter efficiency for each of the three subsystems. The front panel has a display that shows the computer directory with text files and interval for recording, in this case at every ten minutes. At the bottom of the front panel the basic operational parameters of PV system: Global irradiance, Ambient air temperature, Plane irradiance, Temperature of the reference cell, Total DC Power and Total $\mathrm{AC}$ power are displayed.

On the same night, the developed software store measurements for that day are sent automatically to the Internet FTP server in a separate text file.

To facilitate integration, processing and analysis of data, by programming in Borland Delphi, PV UDAS Convert software was developed - Figure 14. It imports text files with measurements, converts them into a suitable form and puts them united in a convenient tabular form in Microsoft Excel Sheet Figure 15.

\subsection{Software for monitoring the electricity produced by photovoltaic system}

Measurement of electrical energy generated by PV system is done with three-phase fourquadrant digital electricity meter - Figure 16. It measures active and reactive power exchanged in both directions between the grid and photovoltaic systems. Three single-phase energy meters measure separately the energy produced by each of the three subsystems. All the four meters are also used to monitor the electrical parameters of the alternatingcurrent side of the photovoltaic system.

Meters are connected through specialized communication devices to the PC. Software product DEMC (Figure 17) is used for remote monitoring and reporting of the energy meter [6]. Every ten minutes the software connects to it and reads and saves to a file:

- Records of produced electric energy by time tariffs - daily, peak and night;

- Values of three AC voltages;

- Values of three AC currents;

- AC output values of three phases and in total, representing the operating powers of each of three subsystems and the total for the entire PV system;

- Voltage frequency.

Software product UMPS (Figure 18) runs automatically every 5 days started by a specialized program developed as AutoHotKey script for automation of the actions of computer programs. It communicates with four-quadrant electricity meter for reading and saving to a file of the load profile of active and reactive power and energy of the photovoltaic system. Then the stored data can be represented graphically by a special program module shown in Figure 19.

Data is imported and re-arranged in a convenient tabular form in Microsoft Excel Sheet using Visual Basic macros for Microsoft Excel. This allows creating and analyzing balances of electric power and energy for different periods of time: for example, MS Excel sheet with integrated energy for 15 minute periods of time is shown in Figure 20 and for one day periods of time in Figure 21. 
File Edit Format View Help

$1 ; 109.89 ; 98.38 ; 80.80 ; 0.1497 ;-0.0670 ;-0.2478$;

; 104.39; 92.69; 72.60; 1.6206;0.9618;0.4280;1.1833;0.6940;0.3485;384.236;361.111; 245.580;0.7650;0.6758;

. $5329 ; 281.03 ; 244.28 ; 147.40 ;$

$21 ; 1.5410 ; 0.9638 ; 0.4677 ; 327.411 ; 309.552 ; 291.854 ; 1.0408 ; 0.9320 ; 0.7415 ; 329.29 ; 288.59 ; 228.89 ;$

$22 ; 385.3495 ; 363.1153 ; 341.9400 ; 0.89 ; 0.76 ; 0.59 ; 321.67 ; 277.37 ; 210.06$;

; $276.86 ; 239.66 ; 117.56$

(1) $278.97 ; 244.85 ; 186.14$

; 4277.92

; $09 ; 09: 20: 00 ; 27.11 .2008 ; 3 G C 9,5$

$1 ; 124.78 ; 114.94 ; 103.13 ; 0.2292 ; 0.0229 ;-0.1683$

; 126.51; 113.71; 101.57; 2.0976; $1.6602 ; 1.3820 ; 1.8193 ; 1.3849 ; 0.9845 ; 390.438 ; 368.093 ; 347.823 ; 0.9467 ; 0.8324 ;$ $6877 ; 352.45 ; 306.52 ; 263.57$

$21 ; 2.5746 ; 1.9906 ; 1.4615 ; 344.098 ; 322.443 ; 297.780 ; 1.2662 ; 1.1110 ; 0.9837 ; 416.74 ; 358.48 ; 311.95 ;$

; $350.71: 309.81 ; 249 ; 43$

;; $348.60 ; 311.51 ; 253.65$

$32 ; 383.42 ; 308.09 ; 0.46$;

; 47.00

; $09 ; 09: 30: 00 ; 27.11 .2008 ; 36 C 9,5$;

; $140.34 ; 131.71 ; 120.04 ; 0.2690 ; 0.0747 ;-0.1286$;

122.89; $3516 ; 2.2002 ; 1.5808 ; 2.5746 ; 2.0565 ; 1.6603 ; 392.823 ; 368.978 ; 349.572 ; 1.1754 ; 1.0410 ;$ $8626 ; 435.18 ; 384.02 ; 330.88$;

$21 ; 3.6479 ; 2.9569 ; 2.3361 ; 349.556 ; 330.012 ; 311.192 ; 15319 ; 1.3294 ; 1.1249 ; 510.81 ; 438.78 ; 386.84 ;$

; $392.6640 ; 371.9793 ; 349.8904 ; 1.39 ; 1.18 ; 0.94 ; 502.15 ; 439.92 ; 364.89$

; $454.10 ; 397.01 ; 331.72 ;$

; $451.99 ; 394.24 ; 316.95 ;$

$5 ; 47.00$;

Figure 12. Structure of the monitoring data in saved text files

\begin{tabular}{|c|c|c|c|c|c|c|c|c|c|}
\hline 县UDAS & stem Monitori & & & & & & & & 0 \\
\hline File Exec & Options Help & & & & & & & & \\
\hline Time & $15: 41: 35$ & & & Monitoring $p$ & $\operatorname{am} P$ & VEn & rgement & & 0 \\
\hline Date & 28.10 .2011 & & & Technical & versity & of $\mathrm{C}$ & abrovo & & 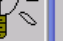 \\
\hline & & saved in & & C:WIPYUpload:Data-f & 20111028 & & Time step 1 & & \\
\hline & /stem1 Polycr & $\mathrm{si} 3,42 \mathrm{~kW}$ & & Sub-System2 Polycris & $\mathrm{Si} 3,42 \mathrm{k}$ & Wp & Sub-System3 Amorph & i $3,22 \mathrm{kWp}$ & \\
\hline T_n & Sub1 & 29.8 & ${ }^{\circ} \mathrm{C}$ & & & & T_mod Sub3 & 37.0 & ${ }^{\circ} \mathrm{C}$ \\
\hline DC & ge Sub1 & 366.4 & V & DC voltage Sub2 & 345 & $.9 \mathrm{~V}$ & DC voltage Sub3 & 299.3 & V \\
\hline$D C$ & ent Sub1 & 5.2 & A & DC current Sub2 & & $8 \mathrm{~A}$ & DC current Sub3 & 5.7 & A \\
\hline$D C F$ & Sub1 & 1891.4 & W & DC power Sub2 & 1996 & $.0 \mathrm{~W}$ & DC power Sub3 & 1695.0 & $w$ \\
\hline$A C$ & Sub1 & 1707.4 & W & AC power Sub2 & 1816 & $1 \mathrm{~W}$ & AC power Sub3 & 1544.9 & W \\
\hline Inve & Efficiency 1 & 0.90 & & Inverter Efficiency 2 & 0. & 91 & Inverter Efficiency 3 & 0.91 & \\
\hline & & & & General $p \varepsilon$ & ters & & & & \\
\hline Amb & Air Temp. & $12.7^{\circ} \mathrm{Y}$ & & Global irradiance & 392.7 & $\mathrm{~W} / \mathrm{m} 2$ & Total DC Power & 5582.3 & W \\
\hline T_re & & $23.9^{\circ}$ & & Plane irradiance & 636.3 & W/m2 & Total AC power & 5058.9 & W \\
\hline Cyo & & 78.0 & ms & & & & & & \\
\hline
\end{tabular}

Figure 13. Front panel of the software for monitoring the PV system of TU - Gabrovo 


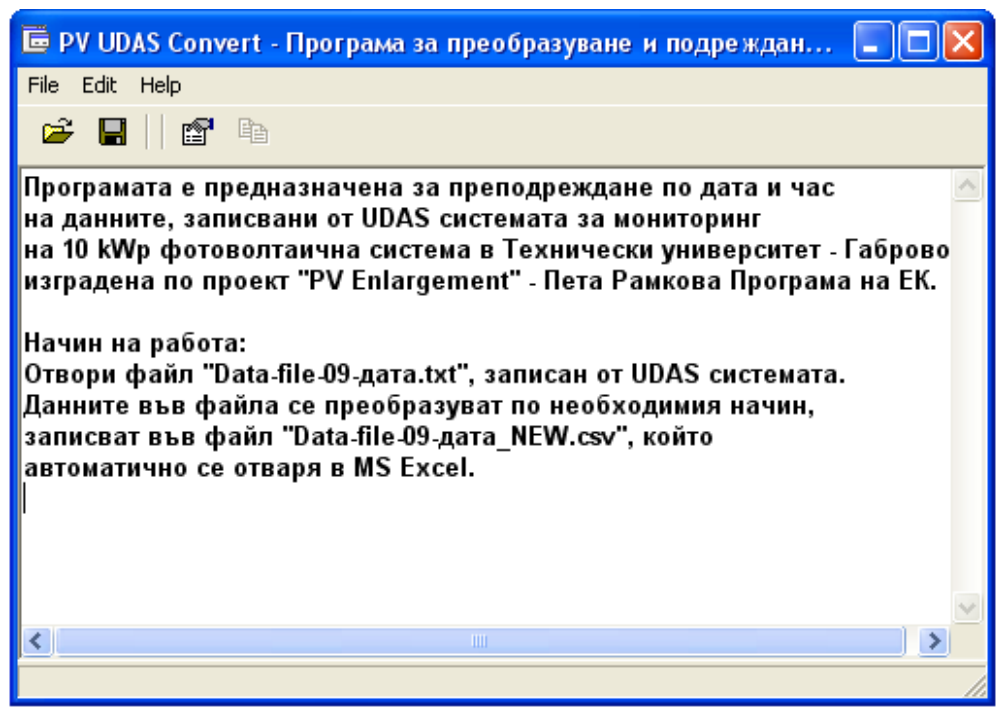

Figure 14. PV UDAS Convert software

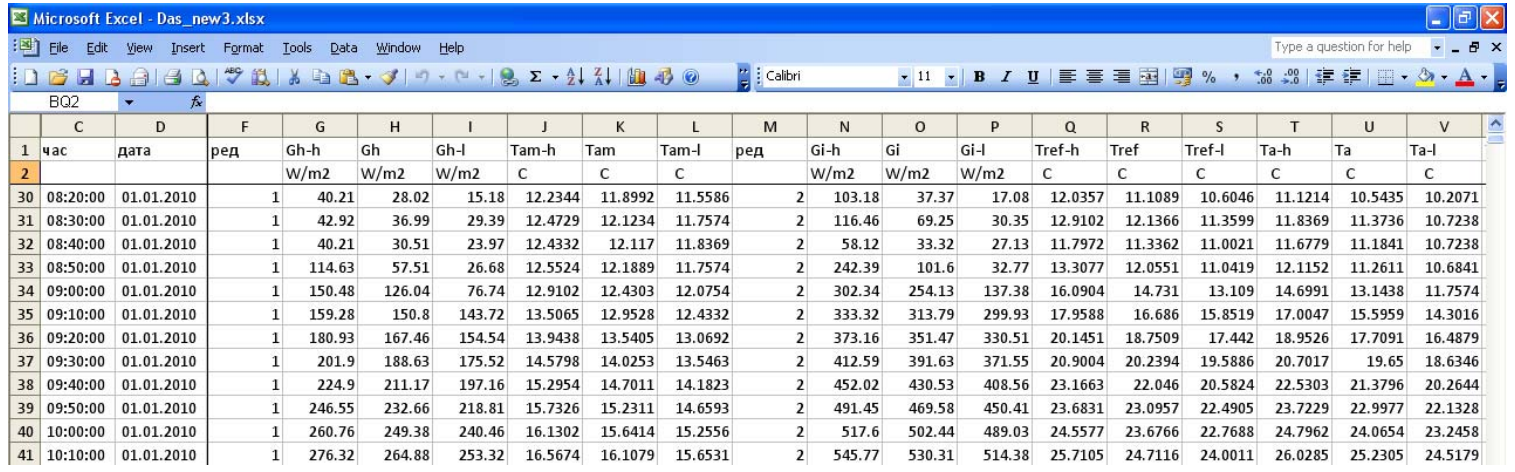

Figure 15. Unified and rearranged PV monitoring data imported in Microsoft Excel Sheet

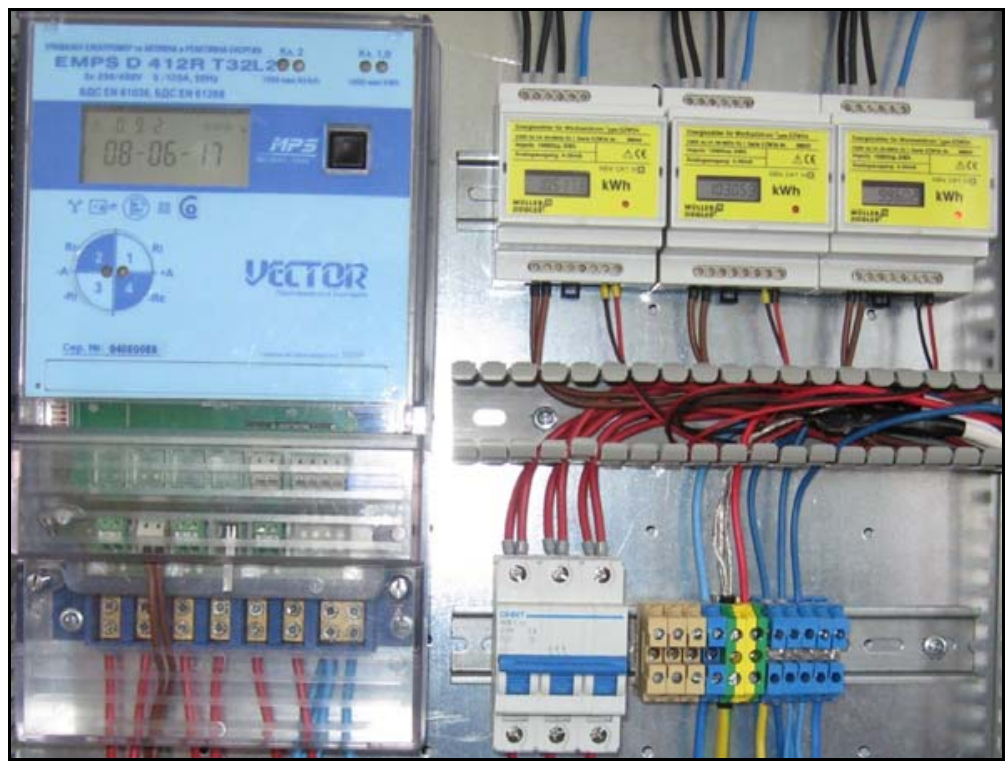

Figure 16. Energy meters used for measuring the electrical energy generated and monitoring the electrical parameters of the alternating-current side of the photovoltaic system 


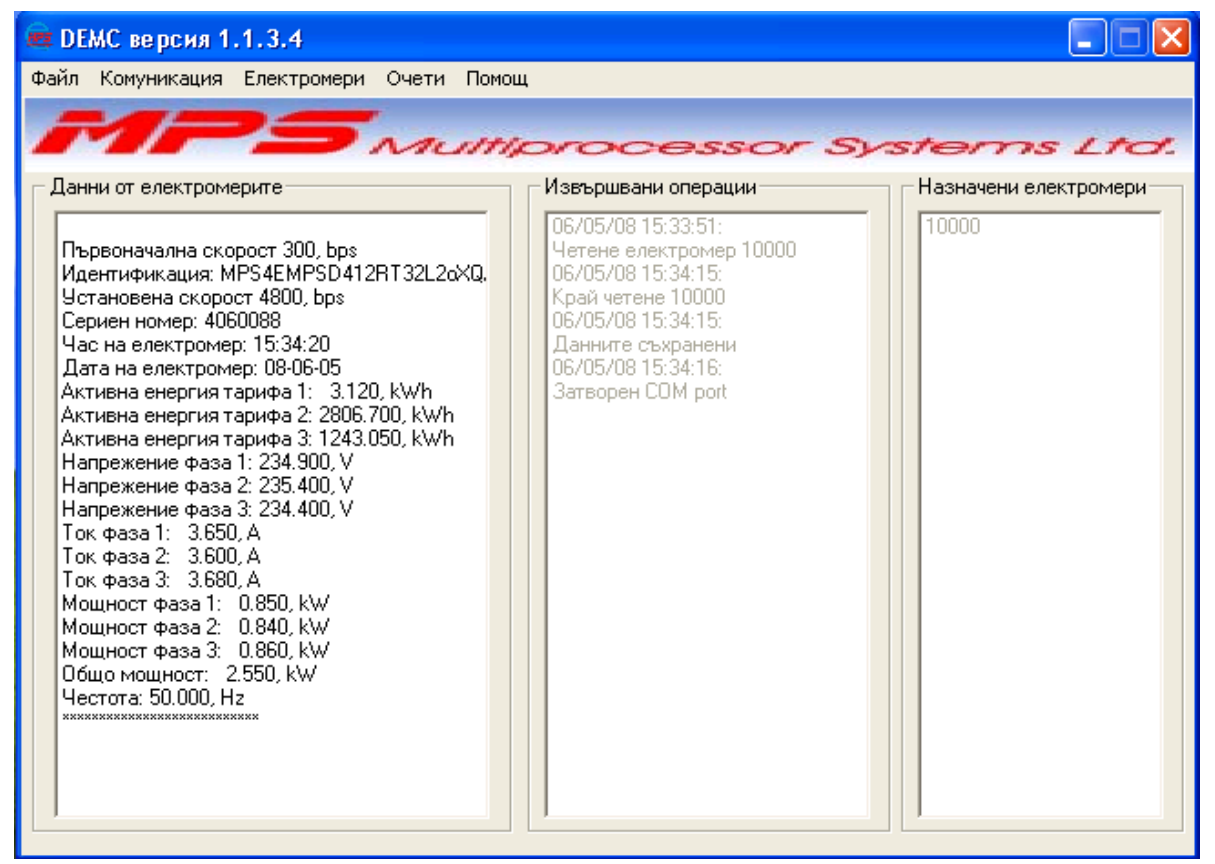

Figure 17. Software Product DEMC for remote monitoring and reporting of the energy meter

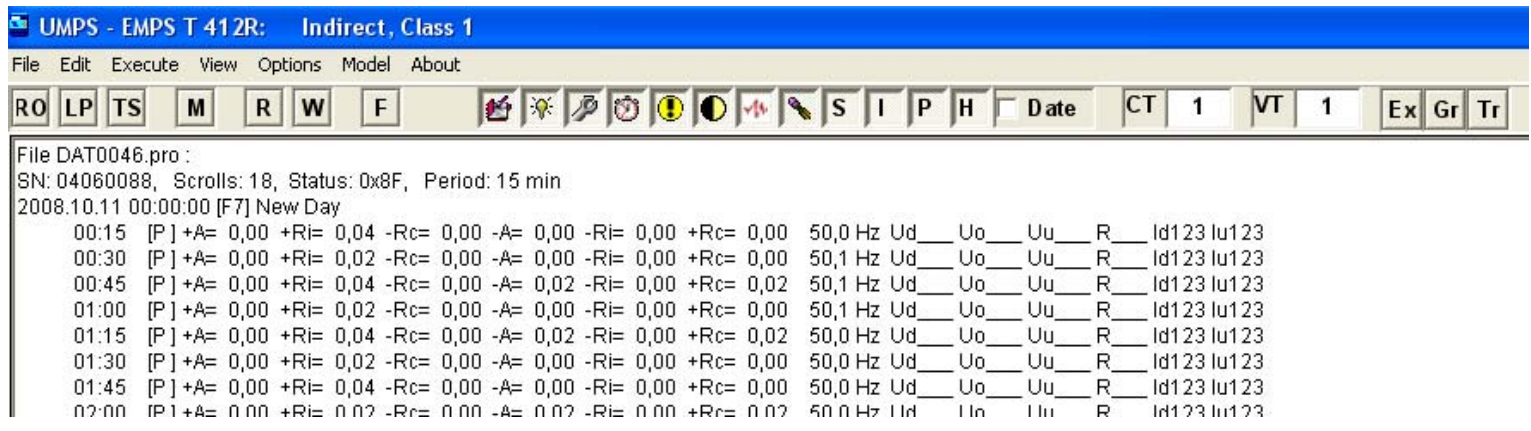

Figure 18. Software product UMPS

2.3. Development of web-based software and database for monitoring $10 \mathrm{kWp}$ photovoltaic system at the Technical University of Gabrovo.

Software products serving the monitoring system generate separate data files with a significant volume. Software of UDAS records, within one year, a total of 2829480 data values in 41610 lines with 68 measurements. This imposes the necessity to choose a method for efficient organization of the information. For this purpose a relational database in programming environment of Microsoft SQL Server Management Studio is developed - Figure 22.

For service and management of the database specialized software PVMonitoring has been developed. The stage of development of the program in
Microsoft Visual Web Developer Express 2010 is shown in Figure 23. An advantage of web-based programs developed in this environment is the possibility to work on a local computer with SQL Server, and also on Internet servers.

PVMonitoring software product automates the process of importing of files recorded by the monitoring system into the database. The functionality of the program also includes the creation of graphical and tabular visualization of the variations of one or more measured quantities for a period of time selected by the user. Figure 24 presents the changes in global irradiance $G h$, plane irradiance $G i$, DC current $I a$, voltage $\mathrm{Va}$ and power $\mathrm{Pa}$ and $\mathrm{AC}$ power Pio of the first subsystem during two days. Figure 25 shows the variations of global irradiance $G h$ and plane irradiance $G i$ for the month of October 2010. 


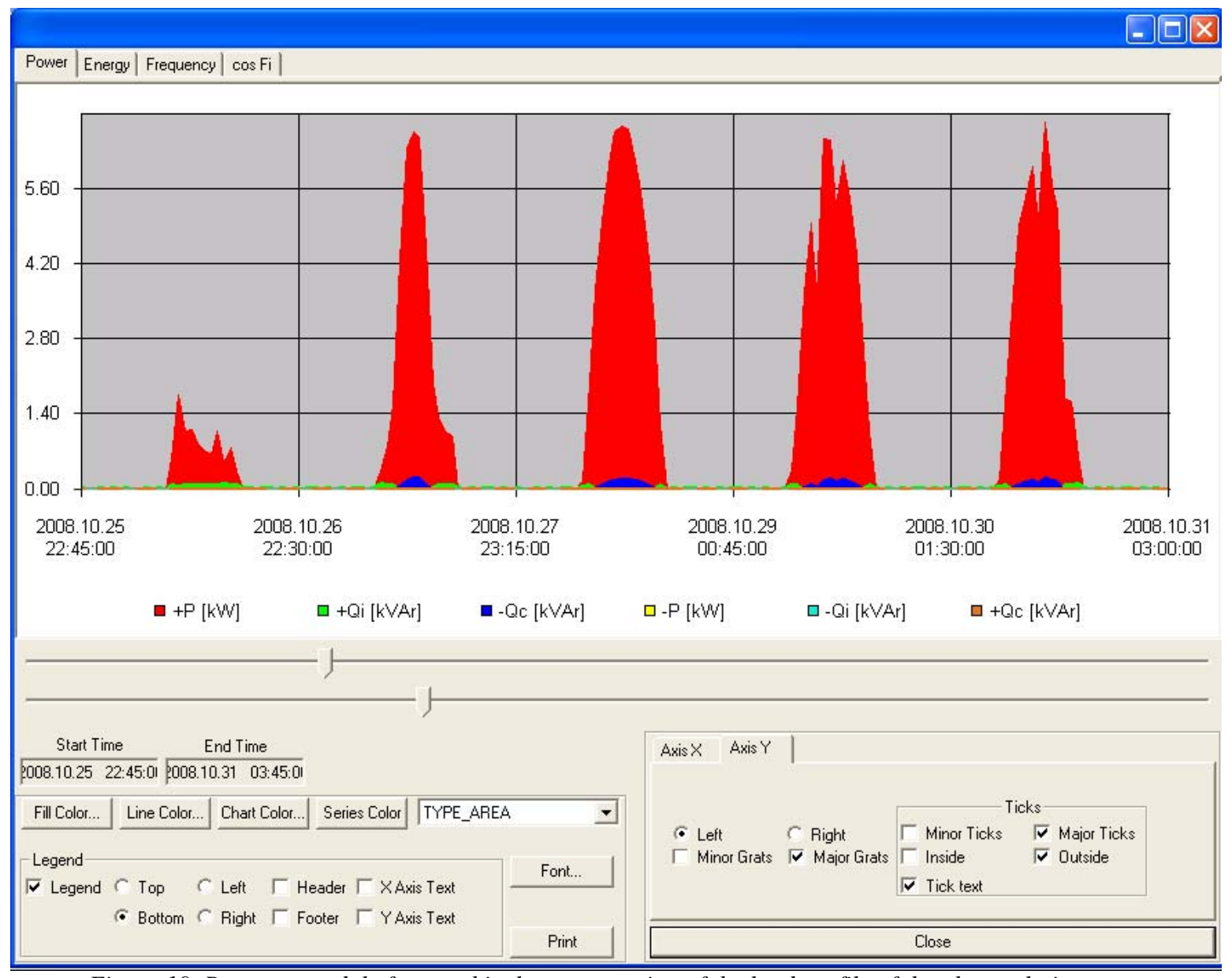

Figure 19. Program module for graphical representation of the load profile of the photovoltaic system

\begin{tabular}{|c|c|c|c|c|c|c|c|c|c|}
\hline 4 & A & B & c & D & E & $\mathrm{F}$ & G & H & 1 \\
\hline 1 & \multicolumn{9}{|c|}{ Консумация на Енергия } \\
\hline 2 & Date & Time & $+\mathrm{A}$ & $+\mathrm{Ri}$ & $-\mathrm{Rc}$ & $-A$ & $-\mathrm{Ri}$ & $+\mathrm{Rc}$ & $\cos \mathrm{Fi}$ \\
\hline 3 & \multicolumn{2}{|c|}{ yy.mm.dd, hh.mm.ss } & kWh & kVArh & kVArh & kWh & kVArh & kVArh & \\
\hline 38211 & 2009.06 .30 & $18: 00: 00$ & 0.3 & 0.015 & 0 & 0 & 0 & 0 & 1 \\
\hline 38212 & 2009.06 .30 & 18:15:00 & 0.29 & 0.015 & 0 & 0 & 0 & 0 & 1 \\
\hline 38213 & 2009.06 .30 & $18: 30: 00$ & 0.175 & 0.02 & 0 & 0 & 0 & 0 & 0.99 \\
\hline 38214 & 2009.06 .30 & $18: 45: 00$ & 0.195 & 0.02 & 0 & 0 & 0 & 0 & 0.99 \\
\hline 38215 & 2009.06 .30 & $18: 50: 53$ & 0.107 & 0.005 & 0.005 & 0 & 0 & 0 & 1 \\
\hline 38216 & 2009.06 .30 & $19: 15: 00$ & 0.089 & 0.012 & 0 & 0 & 0 & 0 & 0.99 \\
\hline
\end{tabular}

Figure 20. Integrated energy for 15-minute periods

\begin{tabular}{|c|c|c|c|c|c|c|c|}
\hline 4 & A & B & C & D & $E$ & $\mathrm{~F}$ & G \\
\hline 1 & \multicolumn{7}{|c|}{ Energy consumption } \\
\hline 2 & Date & $+A$ & $+R \mathrm{R}$ & $-R c$ & $-A$ & -Ri & $+R c$ \\
\hline 195 & yy.mm.dd & kWh & kVArh & kVArh & kWh & kVArh & kVArh \\
\hline 17008 & 2008.12.22 & 12.38 & 0.895 & 0.12 & 0.15 & 0 & 0.145 \\
\hline 17105 & 2008.12.23 & 4.89 & 0.97 & 0.03 & 0.16 & 0.005 & 0.16 \\
\hline 17202 & 2008.12.24 & 16.63 & 1 & 0.27 & 0.135 & 0 & 0.135 \\
\hline 17299 & 2008.12.25 & 10.935 & 1.135 & 0.04 & 0.14 & 0 & 0.135 \\
\hline 17396 & 2008.12.26 & 0.105 & 0.77 & 0 & 0.19 & 0 & 0.195 \\
\hline 17493 & 2008.12.27 & 3.89 & 1.02 & 0 & 0.155 & 0 & 0.155 \\
\hline 17590 & 2008.12.28 & 5.185 & 1.065 & 0 & 0.145 & 0 & 0.14 \\
\hline 17687 & 2008.12.29 & 10.22 & 1 & 0.04 & 0.14 & 0 & 0.14 \\
\hline
\end{tabular}

Figure 21. Integrated energy for one-day periods of time 


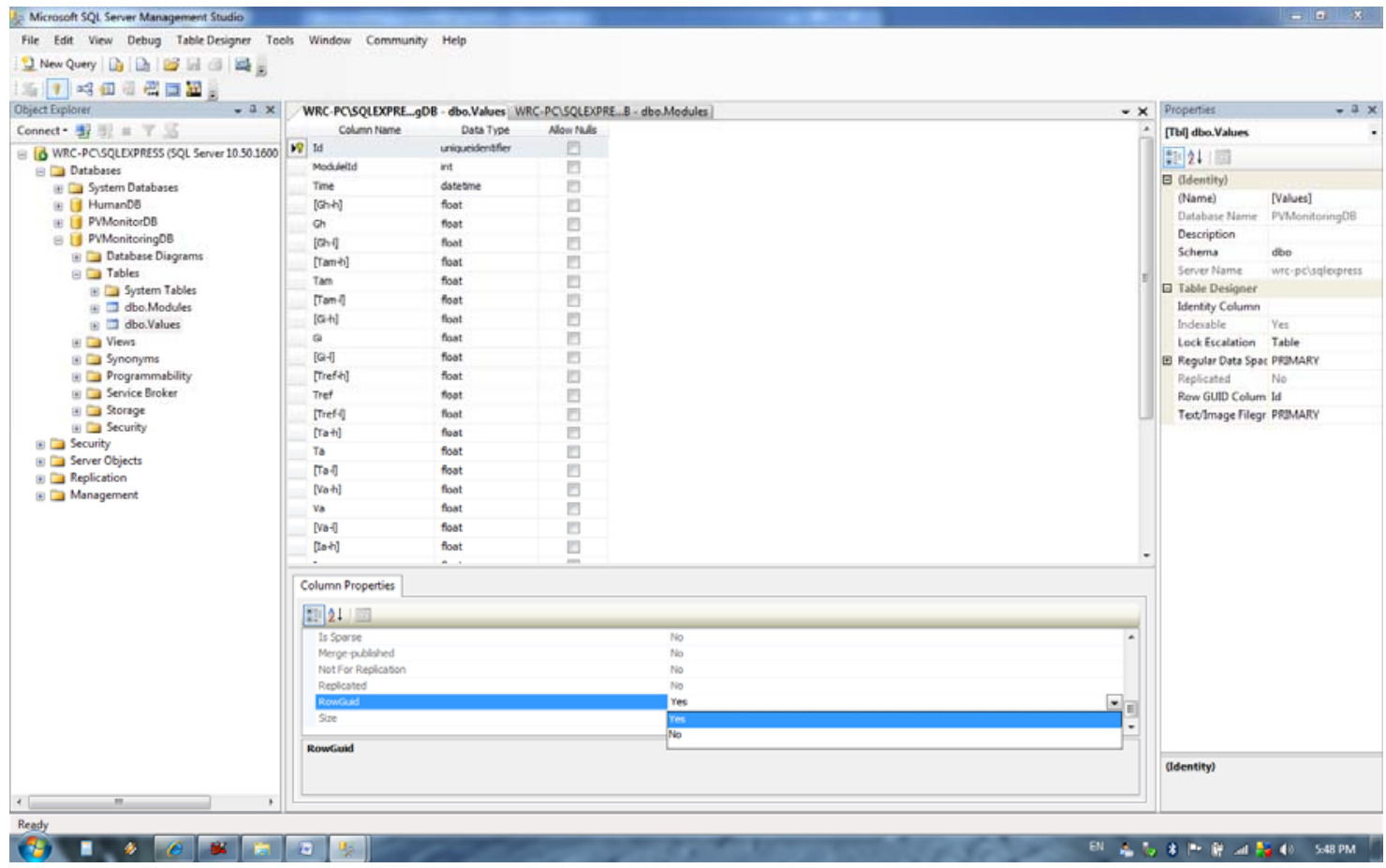

Figure 22. Stage of database development in Microsoft SQL Server Management Studio

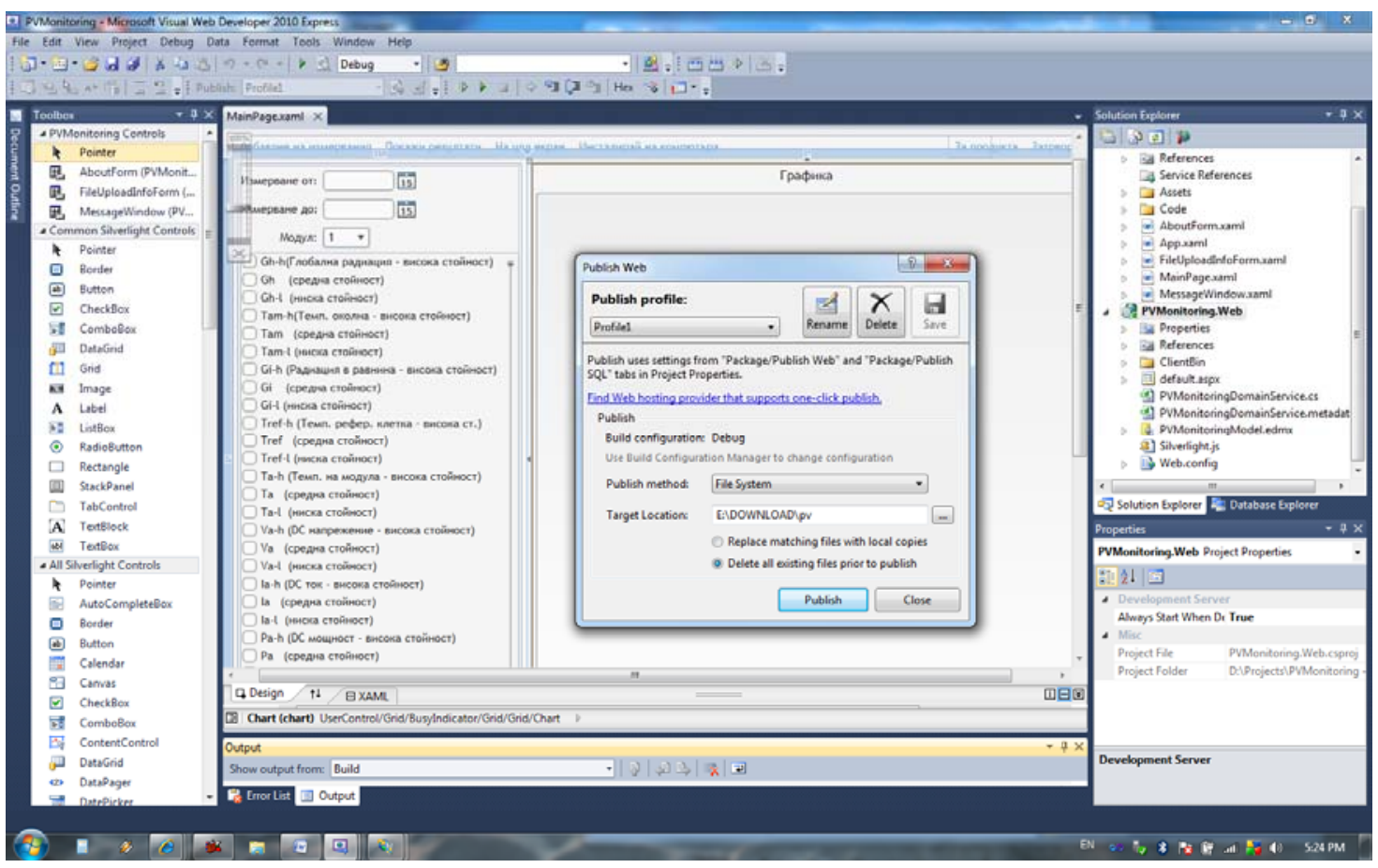

Figure 23. Stage of web-based software PVMonitoring development 


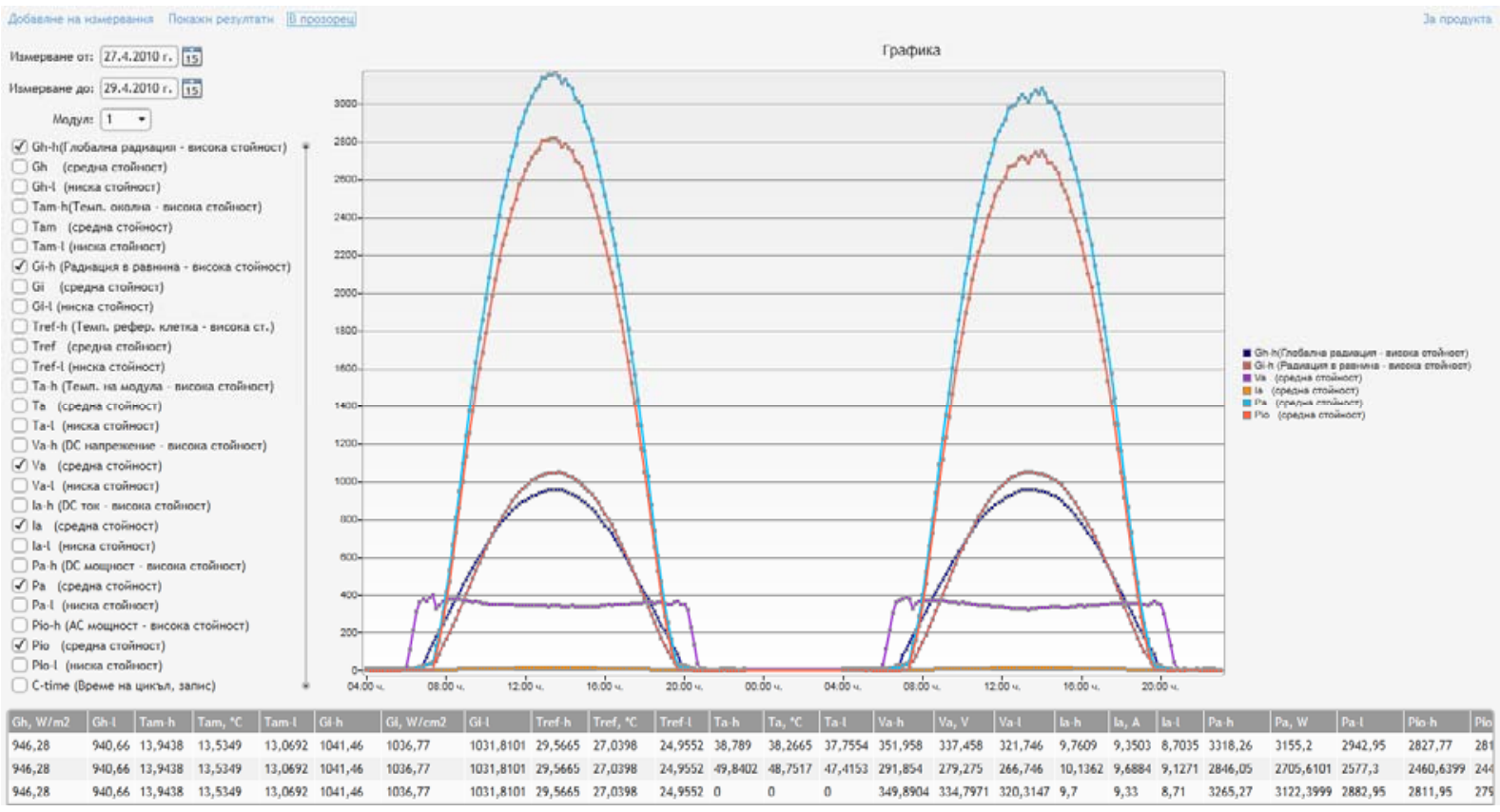

Figure 24. Change of global irradiance Gh, plane irradiance Gi, DC current Ia, voltage Va and power Pa and AC power Pio of the first subsystem during two days

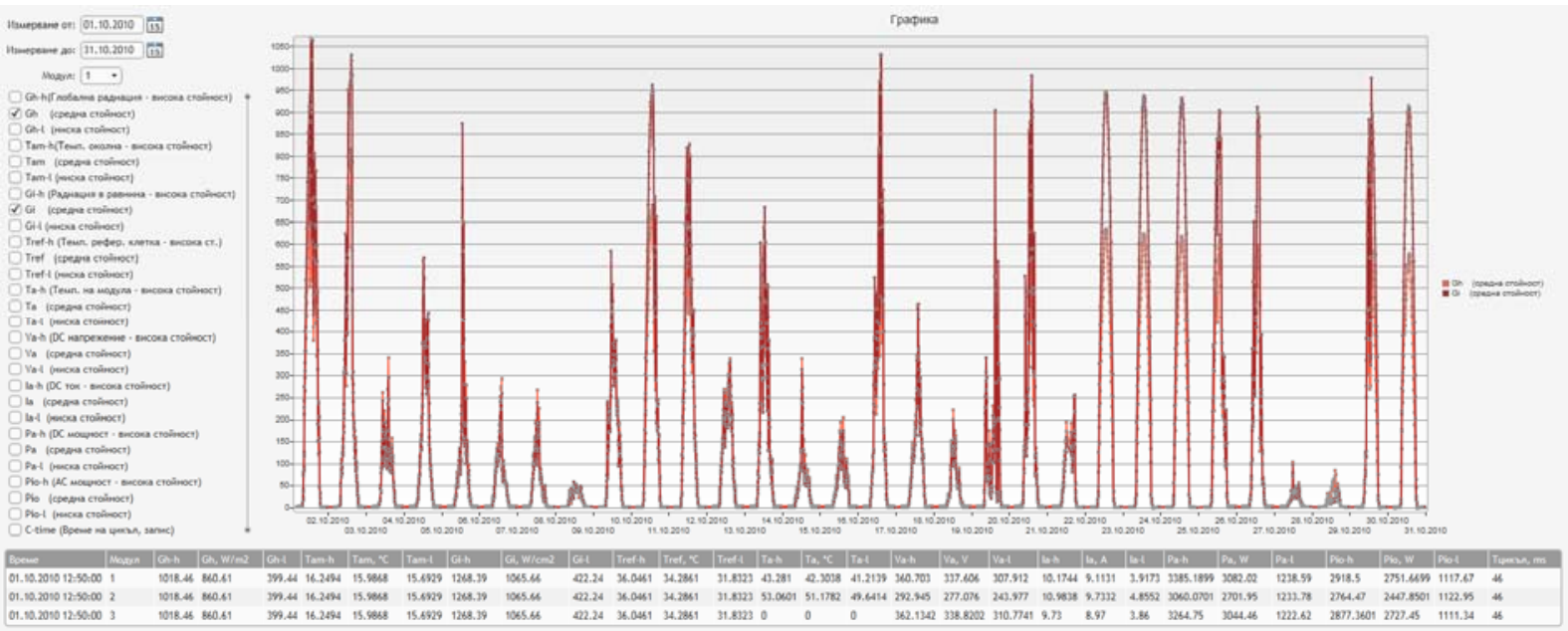

Figure 25. Change of global irradiance Gh and plane irradiance Gi for one month

\section{CONCLUSION}

The developed software package provides reliable measurement and storage of the parameters characterizing the performance of PV system at the Technical University of Gabrovo. Application programming used in contemporary block diagrambased modular development environment allows easy creation of desired functionality and user interface of programs without requiring knowledge of low level programming languages. The developed software products are used successfully in teaching and scientific research activities. Stored in the database operating parameters of the PV system are the bases for research in real conditions of the change over time in the characteristics of polycrystalline and amorphous silicon photovoltaic modules. Continuous monitoring of meteorological and energy parameters of the work of one of the first grid connected PV systems in the region is important for assessing the potential for production of electricity from photovoltaics in Bulgaria and the Balkans. 


\section{REFERENCES}

[1] S. Platikanov, P. Tsankov, D. Markova, M. Petkov, University Photovoltaic System In Gabrovo, Scientific Conference Proceedings UNITECH'08, Gabrovo 2008, III-37-III-44.

[2] P. Tsankov, S. Platikanov, D. Markova, Monitoring System For University Photovoltaic Installation, Scientific Conference Proceedings UNITECH'08, Gabrovo, I-54-I-57.

[3] UDAS-1001E Series Hardware User Manual, Burr-Brown Company, Tucson, Arizona, USA, 2000,1.1-1.4.
[4] UDAS 1001-E Series U-Link Software Libraries User Manual, Burr-Brown Company, Tucson, Arizona, 2000.

[5] Visual Designer User's Manual, PCI20901S Ver. 4.0, Intelligent Instrumentation Inc., Tucson, Arizona, 1997.

[6] System for remote monitoring and reporting of energy consumption DEMC 1.0.2.3, Multiprocessor Systems Ltd, Sofia, 2006.

$\sec 6$

\section{СОФТВЕР ЗА ПРАЋЕЮЕ ФОТОНАПОНСКЕ ЕЛЕКТРАНЕ ПРИКЉУЧЕНЕ НА МРЕЖУ}

Сажетак: У овом раду представљени су софтверски производи који служе за надзор система фотонапонске $(Ф \mathrm{H})$ електране од $10 \mathrm{kWp}$ прикључене на мрежу на Техничком универзитету у Габрову. Израђени су софтверски производи за праћење метеоролошких и електрооперативних параметара, производње електричне енергије и интернетске базе података за ФН систем. Приказани су подаци о окружењу за израду софтвера, фазама програмирања и о функционалности програма.

Кључне ријечи: аморфни и поликристални фотонапонски модули од силицијума, надзор ФН система, израда софтвера заснована на блок дијаграму. 